\title{
Reviewing customer value literature: Comparing and contrasting customer values perspectives
}

\author{
Aija Paananen, Marko Seppänen \\ Center for Innovation and Technology Research (CITER), Tampere University of Technology \\ (Finland) \\ aija.paananen@tut.fi $\_$marko.seppanen@tut.fi
}

Received December, 2012

Accepted August, 2013

\section{Abstract}

Purpose: The paper provides a comprehensive and up-to-date literature review of customer value concepts and distinguishes complex customer value from the various perspectives. It structures the themes and dimensions between the various approaches along the customer value main lines in the literature.

Design/methodology/approach: The paper reviews current literature and illustrates different types of value representations through a case example.

Findings: Based on a comprehensive literature review, a framework how to scholars can structure customer value constructs is presented.

Originality/value: In business and management research a conceptual confusion prevails and this paper attempts to clarify different types of customer value to provide a better resolution tool for scholars.

Keywords: Customer, Value, Management, Review, Definition, Structure

Jel Codes: L10, M10 


\section{Introduction}

Customer value is, broadly speaking, about understanding users today, seeking future opportunities for buyers, and intelligently creating innovations for payers. Traditionally, customer value is conceptually placed between a company's resources and market outcomes that embody the financial purpose of the business; customer value complements technology, and technology is seen as an enabler of customer value. More recently, interdisciplinary literature on customer value has been widely adopted in various science fields: in psychology (Haugtvedt, Herr \& Kardes, 2008), social values (Kahle \& Xie, 2008), economics (Camerer \& Fehr, 2006), and even neurosciences (Fellows, 2004). Customer value, and its applications, has been adopted in marketing (Sanchez-Fernandez \& Iniesta-Bonillo, 2007) and the business and management sciences (Woodruff, 1997; Woodall, 2003; Sheth \& Mittal, 2004). In the field of business and management, conceptual confusion in customer value research has occurred primarily due to the dynamic nature of customer value. Thus, there is still room for future study of the unresolved issues recognized in value theory, such as the origins and changing conditions of customer values (Kahle \& Xie, 2008) and the dynamic nature of perceived value (Sanchez-Fernandez \& Iniesta-Bonillo, 2007) from different perspectives.

Hence, motivated by the conceptual obscurity of customer value, the objective of this study is to give structure to the customer value literature. We aim at increasing understanding of the dynamic antecedents and activities of customer value across four perspectives-value for one customer, value for customers, value for a company, and value for companies. Accordingly, the research question is to conceptually structure the customer value literature. The question is rather broad; thus, the target of the study builds the blocks through the literature review method and an illustrative case analysis. The review reveals the emergence of customer value and several insights. In particular, managing customer value is about understanding different value perspectives, components, and dynamics. Potential economic values play an important role in the various conceptualizations of customer values (Peppers \& Rogers, 2005).

Our objectives are twofold: to provide a comprehensive and up-to-date literature review of customer value concepts and to distinguish complex customer value from the various perspectives and attempt to structure the themes and dimensions between the various approaches along the customer value main lines in the literature. This should facilitate future research on the topic. The structure of the study is as follows. First, in the customer value concept section, we elaborate multifaceted definitions and representations of customer value.

In the customer value in business section, we discuss the dynamics of customer values and thematically construct the structure of customer values. In the discussion section, we discuss 
limitations and future research, and then conclude the paper with suggestions for future studies.

\section{Customer value}

The English word value comes from the French verb valoir, which means "to be worth." Originally, value was a philosophical concept about morality and virtuous living. The concept evolved to imply worthiness and valour over time (Kahle \& Xie, 2008). Values are "centrally held, enduring core beliefs, desired end-states, or higher order goals of the individual customer or customer organization that guide behavior" (Flint, Woodruff \& Gardial, 1997).

Since the concept of a customer became prevalent in the early 1960 s in the academic literature (Keith, 1960), customer value has been gathering momentum (Lindgreen, Hingley, Grant \& Morgan, 2012), although the customer value definition is highly debated (Zubac, Hubbard \& Johnson, 2009) and, surprisingly, often studied without an explicit definition of the concept.

Conceptual confusion in business and management customer value research has occurred primarily because of the dynamic nature of customer value. Previous studies state that a customer can perceive value consciously, unconsciously, or pre-consciously (Gorth \& Dye, 1999); thus, a customer perceives value differently. Each customer has her own value model based upon her needs and desires (Ravald \& Grönroos, 1996), demographics or characteristics (Bolton \& Drew, 1991), and financial resources (Ravald \& Grönroos, 1996; Bolton \& Drew, 1991; Zeithaml, 1988). One custoer may be influenced more by potential sacrifices than by benefits (Ravald \& Grönnroos, 1996; Bolton, 1998), while another customer seeks enhanced benefits to compensate (Ostrom \& Iacobucci, 1995). Hence, customer value studies rely on the idea of cost versus benefits (Payne $\&$ Holt, 2001). In Table 1, we present major customer value definitions and citations from the Web of Science and Google Scholar.

At the general level, customer value has been referred to as an overall assessment (Zeithaml, 1988), a function of consumption behavior (Sheth, Newman \& Gross, 1991), perceived quality adjusted for the relative price (Gale, 1994), emotional bond (Butz \& Goodstein, 1996), relationship (Payne \& Holt, 2001), personal perception (Woodall, 2003), and subjective personal introspection (Holbrook, 2005). Existing definitions partially overlap, reinforcing many interpretations. 


\begin{tabular}{|c|c|c|}
\hline Authors, (year) & $\begin{array}{c}\text { Citations } \\
\text { from Google } \\
\text { Scholars (Dec } \\
\mathbf{8}, \mathbf{2 0 1 2})\end{array}$ & Definition \\
\hline Zeithaml (1988) & 6574 & $\begin{array}{l}\text { "Perceived value is the consumer's overall assessment of the } \\
\text { utility of a product based on perceptions of what is received } \\
\text { and what is given." }\end{array}$ \\
\hline $\begin{array}{l}\text { Sheth, Newman and } \\
\text { Gross. (1991) }\end{array}$ & 894 & $\begin{array}{l}\text { The five values influencing market choice behaviour are } \\
\text { functional value, social value, emotional value, epistemic value } \\
\text { and conditional value }\end{array}$ \\
\hline $\begin{array}{l}\text { Butz \& Goodstein } \\
(1996)\end{array}$ & 330 & $\begin{array}{l}\text { By customer value is meant the emotional blond established } \\
\text { between a customer and a producer after the customer had } \\
\text { used a salient product or service produced by that supplier } \\
\text { and found the product to provide an added value }\end{array}$ \\
\hline Woodruff (1997) & 2365 & $\begin{array}{l}\text { "Customer value is a customer's perceived preference for an } \\
\text { evaluation of those product attributes, attribute performances, } \\
\text { and consequences arising from use that facilitate (or block) } \\
\text { achieving the customer's goals and purposes in use } \\
\text { situations." }\end{array}$ \\
\hline $\begin{array}{l}\text { Eggert \& Wolfgang } \\
(2002)\end{array}$ & 482 & $\begin{array}{l}\text { In the B2B-context, customer perceived value is } \\
\text { conceptualized by cognitive construct, pre-/post-purchase } \\
\text { perspective, strategic orientation, present and potential } \\
\text { customers and suppliers' and competitors' offerings }\end{array}$ \\
\hline $\begin{array}{l}\text { Chen \& Dubinsky } \\
\text { (2003) }\end{array}$ & 404 & $\begin{array}{l}\text { "Customer value is defined as a consumer's perception of net } \\
\text { benefits gained in exchange for the costs incurred in obtaining } \\
\text { the desired benefits." }\end{array}$ \\
\hline Woodall (2003) & 226 & $\begin{array}{l}\text { "Value for the customer is any demand-side, personal } \\
\text { perception of advantage arising out of a customer's } \\
\text { association with an organization's offering, and can occur as } \\
\text { reduction in sacrifice and benefit (determined and expressed } \\
\text { either rationally or intuitively); or an aggregation, over time, } \\
\text { of any of all of those." }\end{array}$ \\
\hline Holbrook (2005) & 101 & $\begin{array}{l}\text { Customer value is } 1 \text { ) interactive; } 2 \text { ) relativistic: a) comparison } \\
\text { of objects; b) differs between persons; c) situation dependent; } \\
\text { 3)embodies preferences; } 4 \text { ) is attached not to the object itself } \\
\text { but rather to the relevant consumption experience. }\end{array}$ \\
\hline $\begin{array}{l}\text { Pynnönen, Ritala \& } \\
\text { Hallikas (2011) }\end{array}$ & 10 & $\begin{array}{l}\text { The systemic customer value reflects the value delivered to } \\
\text { the customer is dependent on more than one attribute, and } \\
\text { possibly on more than one firm. }\end{array}$ \\
\hline
\end{tabular}

Table 1. Customer value definitions in chronological order

Customer value is a multi-faceted concept with many meanings and connotations. Some researchers view customer value as closer to the individual (Sheth et al., 1991; Butz \& Goodstein, 1996), others place it closer to the utility (Woodruff, 1997; Zeithaml, 1988), and others still put it between consumption and business (Woodall, 2003; Holbrook, 2005). Briefly, customer value can be viewed as "an (1) interactive, (2) relativistic [(a) comparative, (b) personal, and (c) situational), (3) preference and (4) experience" (Holbrook, 2005). Accordingly, the characteristics of customers' values are diverse. Customers' values are, according to Holbrook (2005), interactive, in the sense that they involve a relationship between some customer and some product or service. They are relativistic, because they 
reflect comparative product and service attributes; they differ between customers and depend on the time and situation. Customers' values embody preferences and are further relevant to consumption experiences (Holbrook, 2005). Hence, the customer value focus involves simultaneous consideration of the content and process of the value of doing business, which explains part of the challenge in defining and operationalizing the concept.

Hence, in contrast to managerial literature, value for customer(s) may not be limited to customer needs and wants (Ulwick, 2005), consumer values (Kahle \& Xie, 2008), product or service attributes (Spiteri \& Dion, 2004), price and quality (Gale, 1994; Monroe \& Chapman, 1987), or innovation adoption decisions (Rogers, 2003).

The centrality of the dynamics in the customer value literature is apparent from the various definitions of customer value. Customer value may accumulate from terminal values (Kahle \& Xie, 2008; Hsu \& Lin, 2006) through derived value (Woodall, 2003) until lifetime value (Bolton, Lemon \& Verhoef, 2004; Stahl, Matzler \& Hinterhuber, 2003). Thus, even though value is appropriated by the focal technology or service, value for the customer is expected, experienced, and/or evaluated (Fellows, 2004; Egidi, Nusbaum \& Cacioppo, 2008) through the focal technologies and services in concert with dynamic and strategic customer value activities.

Mechanisms, such as the means-end elements (Hsu \& Lin, 2006), user acceptance (Davis 1989), or values and lifestyle (Kahle, Beatty \& Homer, 1986), may influence outcomes and consequences customer satisfaction (Woodruff \& Gardial, 1996), customer delight (Rust \& Oliver, 2000), loyalty (Oliver, 1999b), and customer behavior (Sheth \& Mittal, 2004). More broadly, value for the customer forms (Woodall, 2003), and the diffusion of accumulated innovations (Rogers, 2003) influences customers' sacrifices and benefits, including attributes and outcomes (Woodall, 2003), thus furthering the relationship value (Payne \& Holt, 2001; Howden \& Pressey, 2008).

Even predicting customer value changes (Woodruff \& Gardial, 1996) may not guarantee an ability to anticipate changes of social values (Kahle et al., 1986). Thus, understanding the magnitude of the rewards (Fellows, 2004; Holbrook, 2005; Ulwick, 2005) and managing the rewards as goals (Baumgartner \& Pieters, 2008) may help in understanding the development of customer values and further relationship value management (Payne \& Holt, 2001) with existing customers.

In many customer value definitions, the activity perspective is either implicitly or explicitly recurrent. Many scholars include activities for support customer value (Lindgreen et al., 2012), either performed by companies (Eggert \& Wolfgang, 2002; Hooper, Steeple \& Winters, 2001) or perceived by customers (Hsu \& Lin, 2006), as part of their conceptualization. The customer 
value promotes multiple perspectives on value assessment and economic value benefit. Many examinations proposed to represent customer value can be investigated as systems of interactions in business.

\section{Customer value in business}

When a business transaction takes place, it confirms that a customer has perceived enough value to agree to the offering. Nevertheless, why a customer ultimately accepts the offering remains unclear. What value does she perceive? Business management scholars have observed that customers may use the same criteria for judging value ex ante or ex post (Oliver, 1999a; Parasuraman, 1997). Different aspects of values for customers have different impacts at different points in the consumption process (Zeithaml, 1988; LeBlanc \& Nguyen, 1999). Transaction and relativism are recurrent dynamic components in various definitions that have been provided (see Table 1). The emergence and extensive use of customer value have been further driven by several themes, such as consumer values (Zeithaml, 1988), brand values (Christopher, 1996), customer satisfaction and service quality (Parasuraman, Zeithaml \& Berry, 1988; Parasuraman, Berry \& Zeithaml, 1991), value chain (Porter 1991), creating and delivering superior customer value (Slater \& Narver, 1994, 2000), customer's value to the firm, customer-perceived value (Woodruff 1997; Zeithaml, 1988), customer value and shareholder value (Stahl et al., 2003), value process and relationships (Payne \& Holt, 2001), systemic customer value (Pynnönen, Ritala \& Hallikas, 2011), and, currently, value in business and industrial marketing (Lindgreen et al., 2012).

Consumption nature is often attributed to customer value (e.g., Woodruff, 1997) and customer lifetime value (Bolton et al., 2004). Other perspectives include value assessment in lean thinking (Hines, Holweg \& Rich, 2004) or agile manufacturing (Hooper et al., 2001). Concerning business appraisals, value proposition (Anderson, Narus \& Van Rossum, 2006) and brand value (Christopher, 1996) have also been suggested. Some scholars emphasize mechanisms through which business antecedents (Spiteri \& Dion, 2004) create and produce value, such as competence and investments (Spiteri \& Dion, 2004) and total quality management (Hsu \& Lin, 2006), or ultimate value measured with sales contests (Garrett \& Gopalakrishna, 2010), or return to investors and other stakeholders (Applegate, 2001). Indirect perspectives were also proposed by pointing to the outcomes and consequences of customer value, such as relationship value (Howden \& Pressey, 2008), competence and relational value (Zerbini, Golfetto \& Gibbert, 2007), or even triggers for change (Flint et al., 1997). 
In addition to embedding technology in attractive products and services, a firm needs to design a business model (Zott, Amit \& Massa, 2011) and business ecosystem (Adner \& Kapoor, 2010) to fully realize the firm's economic value potential. Customer value could matter even more for disruptive technologies than developing a final product for general purposes. Business models (Chesbrough \& Rosenbloom, 2002) influence the representation and design of value.

Customer value can be seen as an outcome of managerial and industrial mechanisms (Teece, 2010) or as a consequence that connects a company's innovative technology to customer needs. One important role of customer value refers to the economic value potential of new technologies, including two complementary ideas as follows (Zott et al., 2011). First, companies commercialize innovative ideas and technologies aiming for return on customer (Peppers \& Rogers 2005) and increasing corporate performance (Sheth \& Mittal, 2004), thus providing unexpected value for customers. Second, customer value represents a new theme of innovation (Flint, 2002), which further complements processes, products, and organizational innovations, thus providing expected but formerly undelivered value for the customer. The actions may be pursued through base, growth, networking, and learning potential (Stahl et al., 2003) and finally competitive advantage (Parasuraman, 1997). The latter involves relationship value (Howden \& Pressey, 2008) in new forms of collaboration and cooperation and provides a return on the customer, and thus value for the company.

Customer values not only entail consequences for technical innovations but also can be shaped by them (Teece, 2010). Studies show how new product ideation (Flint, 2002) or innovation can trigger changes in the company's operational and commercial activities (Flint et al., 1997), and hence the design mechanisms to create customer value. Although these studies examined the role of customer values in commercializing technologies at the level of the individual firm, more recently it has been pointed out the potential importance of customer value for entire industries. Researchers claim that customer value is systemic and dependent on more than one attribute, and possibly on more than one firm (Pynnönen, Ritala \& Hallikas, 2011). Hence, not limited to organizational change (Goodstein \& Butz, 1998), customer value is introduced as part of the comprehensive reasons for thinking about the systemic change of customer values in the ecosystem.

To develop and manage customer value, companies need to create quality and service that customers can perceive. There are several ways to develop and manage customer value: 1 ) understanding the magnitude of the rewards (Fellows, 2004; Holbrook, 2005; Ulwick, 2005) and managing rewards as goals (Baumgartner \& Pieters, 2008); 2) managing the relationship value (Payne \& Holt, 2001); 3) inter-firm relational drivers (Palmatier, 2008) and linking customer lifetime value with shareholder value (Stahl et al., 2003); and 4) measuring 
customer-perceived value in business markets (Ulaga \& Chacour, 2001) and intelligencegeneration and superior customer value (Slater \& Narver, 2000). Tools for customer value analysis include an events time line, a price and quality profile, and a head-to-head chart (Gale, 1994). Despite the highlighted conceptual differences between customer value and certain aspects of economics, scholars have also emphasized that customer value can play an important role in a firm's economics and further in shareholder value (Applegate, 2001).

In Table 2, the cited literature is synthesized through four perspectives (from one to many customers and from one to many companies) in the columns and different dimensions (based on (Zott et al., 2011)) in the rows. We added two dimensions to the existing dimensions to reflect dynamics with a future perspective (changes in customer values and activities for development and management).

\begin{tabular}{|c|c|c|c|c|}
\hline $\begin{array}{c}\text { Structure of } \\
\text { customer value }\end{array}$ & $\begin{array}{l}\text { Values for one } \\
\text { customer }\end{array}$ & $\begin{array}{c}\text { Values for many } \\
\text { customers }\end{array}$ & $\begin{array}{c}\text { Values for one } \\
\text { company }\end{array}$ & $\begin{array}{c}\text { Values for many } \\
\text { companies }\end{array}$ \\
\hline $\begin{array}{l}\text { Main purpose } \\
\text { (why the } \\
\text { customer value } \\
\text { concept is } \\
\text { offered) }\end{array}$ & $\begin{array}{l}\text { To describe } \\
\text { antecedents of } \\
\text { customer values. } \\
\text { To offer taxonomies } \\
\text { (to which class } \\
\text { does an observed } \\
\text { customer value } \\
\text { belong to?) }\end{array}$ & $\begin{array}{l}\text { To understand and } \\
\text { construct } \\
\text { components of } \\
\text { customers' values } \\
\text { converted into } \\
\text { market customers }\end{array}$ & $\begin{array}{l}\text { To explain how } \\
\text { customer value is } \\
\text { converted into } \\
\text { company } \\
\text { performance }\end{array}$ & $\begin{array}{l}\text { To explain how } \\
\text { customer value is } \\
\text { converted into } \\
\text { corporate } \\
\text { performances }\end{array}$ \\
\hline $\begin{array}{l}\text { What customer } \\
\text { value is not } \\
\text { (limited to) }\end{array}$ & $\begin{array}{l}\text { Customer values } \\
\text { (Kahle \& Xie, } \\
\text { 2008). Customer } \\
\text { needs and wants } \\
\text { (Ulwick, 2005) }\end{array}$ & $\begin{array}{l}\text { Product or service } \\
\text { attributes (Spiteri } \\
\text { \& Dion, 2004). } \\
\text { Price and quality } \\
\text { (Gale, 1994; } \\
\text { Monroe \& } \\
\text { Chapman, 1987). } \\
\text { Adoption decisions } \\
\text { (Rogers, 2003) }\end{array}$ & $\begin{array}{l}\text { Lean thinking } \\
\text { (Hines, Holweg \& } \\
\text { Rich, 2004). Agile } \\
\text { manufacturing } \\
\text { (Hooper, Steeple \& } \\
\text { Winters, 2001) }\end{array}$ & $\begin{array}{l}\text { Value proposition } \\
\text { (Anderson, Naru \& } \\
\text { Van Rossum, } \\
\text { 2006). Brand value } \\
\text { (Christopher, 1996) }\end{array}$ \\
\hline $\begin{array}{l}\text { Antecedents of } \\
\text { customer values }\end{array}$ & $\begin{array}{l}\text { Terminal values } \\
\text { (Kahle \& Xie, 2008; } \\
\text { Hsu \& Lin, 2006). } \\
\text { Expectations, } \\
\text { experience, } \\
\text { evaluation (Fellows, } \\
\text { 2004; Egidi, } \\
\text { Nusbaum \& } \\
\text { Cacioppo, 2008) }\end{array}$ & $\begin{array}{l}\text { Derived value for } \\
\text { customer (Woodall, } \\
\text { 2003). Customer } \\
\text { lifetime value } \\
\text { (Bolton, Lemon \& } \\
\text { Verhoef, 2004; } \\
\text { Stahl, Matzer \& } \\
\text { Hinterhuber, 2003) }\end{array}$ & $\begin{array}{l}\text { Antecedent of } \\
\text { customer value, } \\
\text { such us } \\
\text { competence, } \\
\text { investments } \\
\text { (Spiteri \& Dion, } \\
\text { 2004). Total quality } \\
\text { management (Hsu } \\
\text { \& Lin, 2006) }\end{array}$ & $\begin{array}{l}\text { Value (measures } \\
\text { the return to } \\
\text { investors and other } \\
\text { stake holders) } \\
\text { (Applegate, 2001). } \\
\text { Sales contests } \\
\text { (Garret \& } \\
\text { Gopalakrishna, } \\
\text { 2010) }\end{array}$ \\
\hline $\begin{array}{l}\text { Mechanisms } \\
\text { through which } \\
\text { customer values } \\
\text { influence } \\
\text { outcomes }\end{array}$ & $\begin{array}{l}\text { Means-end } \\
\text { elements (Hsu \& } \\
\text { Lin, 2006). User } \\
\text { acceptance (Davis, } \\
\text { 1989). Values and } \\
\text { life style (Kahle, } \\
\text { Beatty \& Homer, } \\
\text { 1986) }\end{array}$ & $\begin{array}{l}\text { Value for the } \\
\text { customer forms } \\
\text { (Woodall, 2003). } \\
\text { Diffusion of } \\
\text { innovation (Rogers, } \\
\text { 2003) }\end{array}$ & $\begin{array}{l}\text { Understanding, } \\
\text { creating and } \\
\text { delivering value } \\
\text { (Anderson \& Narus, } \\
\text { 1999). Relationship } \\
\text { marketing (Ravald } \\
\text { \& Grönroos, 1996) }\end{array}$ & $\begin{array}{l}\text { Business models } \\
\text { (Zoot, Amit \& } \\
\text { Massa, 2011; } \\
\text { Chesbrough \& } \\
\text { Rosenbloom, 2002). } \\
\text { The value chain } \\
\text { (Porter, 1991). } \\
\text { Ecosystems (Adner } \\
\text { \& Kapoor, 2010) }\end{array}$ \\
\hline
\end{tabular}




\begin{tabular}{|c|c|c|c|c|}
\hline $\begin{array}{c}\text { Structure of } \\
\text { customer value }\end{array}$ & $\begin{array}{c}\text { Values for one } \\
\text { customer }\end{array}$ & $\begin{array}{c}\text { Values for many } \\
\text { customers }\end{array}$ & $\begin{array}{l}\text { Values for one } \\
\text { company }\end{array}$ & $\begin{array}{c}\text { Values for many } \\
\text { companies }\end{array}$ \\
\hline $\begin{array}{l}\text { Outcomes and } \\
\text { consequences of } \\
\text { customer values }\end{array}$ & $\begin{array}{l}\text { Customer } \\
\text { satisfaction } \\
\text { (Woodruff \& } \\
\text { Gardial, 1996). } \\
\text { Customer delight } \\
\text { (Rust \& } \\
\text { Oliver,2000). } \\
\text { Loyalty (Oliver, } \\
\text { 1996). Customer } \\
\text { behaviour (Sheth \& } \\
\text { Mittal, 2004) }\end{array}$ & $\begin{array}{l}\text { Sacrifices and } \\
\text { benefits incl. } \\
\text { Attributes and } \\
\text { outcomes (Woodall, } \\
\text { 2003). Relationship } \\
\text { value (Payne \& } \\
\text { Holt, 2001; } \\
\text { Howden \& Pressey, } \\
\text { 2008) }\end{array}$ & $\begin{array}{l}\text { Return to customer } \\
\text { (Peppers \& Rogers, } \\
\text { 2005). Corporate } \\
\text { performance } \\
\text { (Sheth \& Mittal, } \\
\text { 2004) }\end{array}$ & $\begin{array}{l}\text { Competitive } \\
\text { advantage } \\
\text { (Parasuraman, } \\
\text { 1997). Base, } \\
\text { growth, networking } \\
\text { and learning } \\
\text { potentials (Stahl, } \\
\text { Matzler \& } \\
\text { Hinterhuber, 2003) }\end{array}$ \\
\hline $\begin{array}{l}\text { Changes in } \\
\text { customer values }\end{array}$ & $\begin{array}{l}\text { Social values and } \\
\text { social change } \\
\text { (Kahle, Beatty \& } \\
\text { Homer, 1986) }\end{array}$ & $\begin{array}{l}\text { Predicting customer } \\
\text { value chances } \\
\text { (Woodruff \& } \\
\text { Gardial, 1996) }\end{array}$ & $\begin{array}{l}\text { Organizational } \\
\text { change (Goodstein } \\
\text { \& Butz, 1998) }\end{array}$ & $\begin{array}{l}\text { Triggers (Flint, } \\
\text { Woodruff \& Gardial, } \\
\text { 1997) }\end{array}$ \\
\hline $\begin{array}{l}\text { Developing and } \\
\text { managing } \\
\text { example } \\
\text { activities for } \\
\text { customer values }\end{array}$ & $\begin{array}{l}\text { Understanding } \\
\text { magnitude of } \\
\text { rewards (Fellows, } \\
\text { 2004; Holbrook, } \\
\text { 2005; Ulwick, } \\
\text { 2005). Managing } \\
\text { rewards as goals } \\
\text { (Baumgartner \& } \\
\text { Pieters, 2008) }\end{array}$ & $\begin{array}{l}\text { Relationship value } \\
\text { management } \\
\text { (Payne \& Holt, } \\
\text { 2001) }\end{array}$ & $\begin{array}{l}\text { Inter-firm relational } \\
\text { drivers of customer } \\
\text { lifetime value with } \\
\text { shareholder value } \\
\text { (Stahl, Matzler \& } \\
\text { Hinterhuber, 2003) }\end{array}$ & $\begin{array}{l}\text { Measuring } \\
\text { customer-perceived } \\
\text { value in business } \\
\text { markets (Ulaga \& } \\
\text { Chacour, 2001). } \\
\text { Intelligent } \\
\text { generation and } \\
\text { superior customer } \\
\text { value (Slater \& } \\
\text { Narver, 2000) }\end{array}$ \\
\hline
\end{tabular}

Table 2. Structure of customer value: Comparing and contrasting customer values perspectives

\section{Case description}

The selected case is a business unit within a multinational wood processing company located in Northern Europe. We chose the case as it is appropriate for illustrating this study based on the availability of and access to data. Data was collected in three phases. First, background information was acquired by reading available information found on the company's website and other secondary data sources. Second, the director and the marketing manager were interviewed with semi-structured questions, focusing on mostly on getting a good overview of how the business has evolved since its inception. Third, we conducted a full-day business model workshop in which three future business scenarios were designed and iterated to support further business development.

In January 2011, the case company announced a new, patent-pending technology for manufacturing layered composites. This innovation provides opportunities for construction, transport, and furniture industries by allowing them to create different product structures more easily and efficiently. The core of the new technology is a special adhesive film that allows products to be re-formed after manufacturing. Further advantages are smaller variations in the forming process, more stable and stronger end products, and the same strength achieved with 
thinner structures. In addition, the adhesive used is free from formaldehyde and other harmful compounds. The material can also be safely recycled or used as a carbon neutral source of energy at the end of life.

There were several options for how a company can position itself to the value network, depending on strategic targets. Being an adhesive film producer would require a lot of network orchestration, and the company would be the focal company; however, then the question is to what extent the company can leverage its position to reap revenues and profits. Other options would mean being more involved in the production process, either providing raw material to furniture manufacturing companies (for example) or even becoming a furniture OEM provider. Each strategic option has a different value proposition. In the following section, we investigate more closely through our theoretical lenses what kinds of phenotypes (expression) customer value may have, by first using the interview data. In the summary section, we use the three types of data we collected.

\section{Results: Analysing data through the structure of customer value}

In this section, we use the proposed theoretical structure of customer value to examine our findings from a single case. We focus on the identified challenges and activities in creating customer value and then summarize the value created. The quotes from the case representatives are presented to illustrate how theoretical concepts of customer value are manifested. Identifying and defining the main purpose of the innovation are often tricky issues for management. Especially, in the early phase of commercialization, the view of customer value was blurred, but it was expected to have commercial value, as discussed as follows:

"We didn't actually have a solution. We had something that could bring value, but we didn't really know what that value was. And but then we had the support of management behind it, but of course at the same time there was still, you could not see commercial value, and we needed investment for something you can't put any value to."

Sufficient quality and the existing processes establish the basis for creating customer value (Gale, 1994; Monroe \& Chapman, 1987). Furthermore, the product was expected to provide value throughout the value chain, as demonstrated in the following:

"The quality was more consistent, it brought greater value in the fact that there were more first quality goods that they have less waste and it's simple. They had a huge value chain all the way through, just getting veneers." 
To provide customer value, many customer value attributes need to be fulfilled (Woodall, 2003). Applying multiple values increases the likelihood of achieving better value for the customers, as emphasized as follows:

"We want this to be value-added, and we don't want this to be something cheap. So we also have to enter places where the, where our cost structure is correct, and not just entering."

Prioritization of certain types of values (Slater \& Narver, 2000), or just having a high value potential, however, does not guarantee success, as discussed as follows:

"I think at this moment we really don't know its true potential, but we have done a lot of patenting, and trying to patent what might be, but when you do perhaps not truly know where it will bring its greatest value, then we have probably missed what it will be."

Understanding how a company creates value through its choices regarding internal and external processes is vital for delivering value that customers appreciate. Identifying appropriate mechanisms (Anderson \& Narus, 1999), for instance, in partner selection, contributes to the real value fulfilment.

"OK, what do you need? You need to material, you need the modifications to your process, a modernization or a complete process, you need the designs, you need the designer, and then you could offer different packages... In at least the furniture industry, I think we have a lot more work to even do there, to find out our real value. ... And then we had to find the right partner, because if we had chosen the wrong company to go with, then, if they didn't see the value, then time would run out and this probably would already be dead."

Hence, aiming at providing customer lifetime value (Stahl et al., 2003) is a target approach when entering new business-to-business (B2B) markets, as demonstrated in the following:

"It's very critical there that you have chosen somebody that understands and values what new ideas and new creations could be, and have the patience to work with you for long enough to see what value it could bring."

Justification for target market selection may relate to earlier experience and achievements (path dependency). Strategic positioning can be based on fundamentals such as base, growth, networking, and learning potentials (Stahl et al., 2003) that can lead managers to support projects even though their expected value is unclear. In particular, the cost of pushing new 
products to markets can be very high. A representative of the case company explains the project scope as follows:

"This, we've entered the furniture industry because, it's, customers, so it's closer, it's using the same customer base we already have with something very different rather than going into totally new end use."

Detailed investigation (Cooper, 2000) and customer value determination (Woodruff, 1997) are challenging, since the expectations of customer needs and wants are resolved. However, a new product may open the door for new markets as illustrated below. Pushing innovative technology to target customers creates a customer need such that customers are likely to value that technology in the future.

"If you're just developing and developing until you find the perfect thing you will either miss it. So you must enter with something that is workable, that has a solution now, but then you must develop the thing that will be what takes that market. . . . If we want to enter new markets we should enter first with the ones where we're not sure, and see how that's accepted."

However, although agreement between the delivered value and its anticipation (Fellows 2004; Egidi et al., 2008) may reinforce the buying behaviour (Sheth \& Mittal, 2004), a mismatch between delivery and value expectancy might dissatisfy the customer. This leads to a discussion of the risks as follows:

"If you enter into those other end uses but you don't know the customers, they don't know this technology and you haven't even got any idea, how can you even offer them anything, any solution?"

A business model concept (Zott et al., 2011; Chesbrough \& Rosenbloom, 2002; Mäkinen \& Seppänen, 2007) provides a device for testing different options to build on in later phases. However, these kinds of ecosystem considerations (Adner \& Kapoor, 2010) require a farreaching view of potential partners and their possible roles in collaboration, as shown in the following:

"Before entering the new end uses we also should in a way recognize and then build this right kind of platform, with all the needed networks, all the needed services, and that everything.. You know, to be in a way that kind of chosen, reliable partner." 
However, the decision to enter markets requires a detailed cost analysis, since the company is building a substituting solution to displace customers' existing solutions for the same purpose.

"It is just a cost game. But if they have the solution that they in a way can get back at least part of their, more, that kind of design, business critical part of the business, they are really glad to do that. But it has to be competitive of course."

In conclusion, evaluating customer value includes target market analysis and potential economic valuation to potentially create competitive and strategic value for the company. Despite the strong industrial experience before and support of the big company, strategic customer value creation includes potential but risks when companies enter new B2B markets.

In Table 3, we summarize our findings based on the background information, interviews, and business model workshops. We use dimensions based on the structure of customer value presented in Table 2. Thus, the following summary (Table 3 ) illustrates how strategic customer value is created in customer value for one company dimension.

\begin{tabular}{|c|c|c|c|}
\hline $\begin{array}{c}\begin{array}{c}\text { Structure of customer } \\
\text { value }\end{array} \\
\text { ald }\end{array}$ & Example & Explanation & $\begin{array}{l}\text { Target of value } \\
\text { creation }\end{array}$ \\
\hline $\begin{array}{l}\text { Main purpose (why } \\
\text { the customer value } \\
\text { concept is offered) }\end{array}$ & $\begin{array}{l}\text { Company has developed } \\
\text { a new way to } \\
\text { manufacture layered } \\
\text { composites. The first } \\
\text { application of the new } \\
\text { technology is formable } \\
\text { innovation }\end{array}$ & $\begin{array}{l}\text { New formable, bends } \\
\text { easily, applicable to } \\
\text { many end uses }\end{array}$ & $\begin{array}{l}\text { Remaining the } \\
\text { company's high quality } \\
\text { trademark and keeping } \\
\text { the performance level. } \\
\text { Marketing and co- } \\
\text { designing activities }\end{array}$ \\
\hline $\begin{array}{l}\text { What customer value } \\
\text { is (not limited to) }\end{array}$ & $\begin{array}{l}\text { The new adhesive bonds } \\
\text { not only wood but many } \\
\text { minerals (rocks, } \\
\text { ceramics etc.), glass, } \\
\text { metals, textiles, paper } \\
\text { and cardboard }\end{array}$ & $\begin{array}{l}\text { Materials can also be } \\
\text { combined to create } \\
\text { multi-material } \\
\text { composites }\end{array}$ & $\begin{array}{l}\text { To be offered other } \\
\text { company products and } \\
\text { services based on other } \\
\text { raw materials than } \\
\text { wood. Potential striving } \\
\text { via activating new } \\
\text { customers }\end{array}$ \\
\hline $\begin{array}{l}\text { Antecedents of } \\
\text { customer values }\end{array}$ & $\begin{array}{l}\text { Empowering company's } \\
\text { personnel with e.g. } \\
\text { product development } \\
\text { enables value creation } \\
\text { activities }\end{array}$ & $\begin{array}{l}\text { Value for customer } \\
\text { influences to likelihood } \\
\text { of customer involvement }\end{array}$ & $\begin{array}{l}\text { Company has (to be) } \\
\text { learned to understand } \\
\text { customers' processes, } \\
\text { what values this could } \\
\text { bring to them }\end{array}$ \\
\hline $\begin{array}{l}\text { Mechanisms through } \\
\text { which customers } \\
\text { values influence } \\
\text { customers }\end{array}$ & $\begin{array}{l}\text { Innovation's glue line is } \\
\text { highly homogeneous and } \\
\text { behaves in a uniform } \\
\text { way on every press. } \\
\text { Variation between } \\
\text { formed component is } \\
\text { minimized }\end{array}$ & $\begin{array}{l}\text { Minimized variation } \\
\text { together with higher } \\
\text { overall strength, will } \\
\text { reduce production } \\
\text { rejects and quality } \\
\text { claims }\end{array}$ & $\begin{array}{l}\text { Innovation is } \\
\text { manufactured of certified } \\
\text { wood raw material }\end{array}$ \\
\hline
\end{tabular}




\begin{tabular}{|c|c|c|c|}
\hline $\begin{array}{c}\text { Structure of customer } \\
\text { value }\end{array}$ & Example & Explanation & $\begin{array}{l}\text { Target of value } \\
\text { creation }\end{array}$ \\
\hline $\begin{array}{l}\text { Outcomes and } \\
\text { consequences of } \\
\text { customer values }\end{array}$ & $\begin{array}{l}\text { Due to the special } \\
\text { adhesive used in } \\
\text { innovation }\end{array}$ & $\begin{array}{l}\text { Component are stronger } \\
\text { and more stable than } \\
\text { traditional form pressed } \\
\text { components }\end{array}$ & $\begin{array}{l}\text { The end use areas of } \\
\text { formable Innovation are } \\
\text { very versatile. Exploring } \\
\text { target customers' plans } \\
\text { for versatility striving via } \\
\text { interview laddering }\end{array}$ \\
\hline $\begin{array}{c}\text { Change in customer } \\
\text { values }\end{array}$ & $\begin{array}{l}\text { Brand and services are } \\
\text { needed to enhance } \\
\text { perceived customer } \\
\text { value, especially in } \\
\text { activities in customer } \\
\text { interface, e.g. training }\end{array}$ & $\begin{array}{l}\text { Value can be conceived } \\
\text { as end products and } \\
\text { services throughout } \\
\text { customers' adoption } \\
\text { processes }\end{array}$ & $\begin{array}{l}\text { The value chain needs } \\
\text { new competence from } \\
\text { the case company }\end{array}$ \\
\hline $\begin{array}{l}\text { Developing and } \\
\text { managing example } \\
\text { activities for customer } \\
\text { values }\end{array}$ & $\begin{array}{l}\text { Innovation enables } \\
\text { furniture manufacturers } \\
\text { to revolutionize their } \\
\text { operation processes }\end{array}$ & $\begin{array}{l}\text { Improvements for form } \\
\text { pressing supply chain, } \\
\text { cut costs and to enhance } \\
\text { production efficiency }\end{array}$ & $\begin{array}{l}\text { The furniture } \\
\text { manufacturers could } \\
\text { take formable Innovation } \\
\text { into use in mass } \\
\text { production. Remaining } \\
\text { as a partner for } \\
\text { implementing the plans }\end{array}$ \\
\hline
\end{tabular}

Table 3. Summary of the findings of customer value creation for a new business market

The analysis shown in Table 3 provides a multifaceted view of customer value through collective thematic lenses in the case of entering new markets in the B2B context. The customer value perspective seeks to explain how value is expected, experienced, and evaluated, not just how it is created and captured. Thus, customer values emphasize a perspective-specific, holistic approach to explaining how potential customers and businesses perceive values. In particular, potential strategic values play an important role in the B2B context. These themes could complement antecedents and dynamics of customer value as catalysts for a more unified study of customer value and emphasize further management of customer value.

\section{Discussion}

In this study, we have shown how customer value has been used to address different research domains in various contexts and academic areas. Scholars have used the term to explain and address various phenomena such as social value, consumer value, value for the customer, and value for the company, and, furthermore, how value is understood, created, and delivered. Hence, the multitude of research on customer value has been scattered. We reviewed the various developments by comparing and contrasting the various approaches to customer value and thus structuring customer value.

The literature review shows that scholars in different fields use the same term to explain different phenomena. In other words, customer value denotes many separate concepts in its current use. Adopting more precise concepts, terminologies, and forms would greatly enhance 
conceptual clarity. In particular, we need more clarity about the theoretical building blocks of customer value, its antecedents and consequences, and the mechanisms through which it rewards and benefits. Examples include terminal values, for unidimensional studies such as in psychology; customer's values for unidimensional studies in utilitarian contexts such as in economics in focusing on the antecedents of customer value before the adoption decision; customers' values in multidimensional studies such as in business and management for explaining activities, mechanisms, and outcomes that allow corporate performance to be developed and managed.

Despite the attempt to rigorously analyze the literature on customer values, this review comes with several limitations. Much of the reviewed literature is diverse; making sense of it is therefore challenging because, for instance, different studies have different assumptions regarding science and knowledge, and different methodological choices have been applied. Customer value remains a theoretically under-constructed, however sometimes overloaded, concept, which raises doubts concerning its usefulness for empirical research and theory building. We used a case study to illustrate the managerial challenges, thus leaving room for future studies to test the framework further, for instance, in the current market offering and B2C contexts.

Scholars need to articulate and define precisely which perspective of customer value they propose to use as a basis for study. Stating clearly whether customer value refers to value for the customer (Woodall, 2003) or to the return on the customer (Peppers \& Rogers, 2005) would bring greater clarity to theoretical development in business and management. Especially business and management researchers have encountered problems in studying customer value. This is mainly because value is perceived by the customer (Woodruff, 1997; Butz \& Goodstein, 1996), and therefore, exists only in the customers' terms. As a result, the presence or nature of customer value is easily misinterpreted. In addition, in competitive markets, customers' values tend to change when the cultural, environmental, or social situations to which people adapt change (John, 1999); thus, customers may not be able to reliably predict what they will value in the future (Woodruff, 1997; Huber et al., 1997), which leads to challenges in business. 


\section{Conclusions}

Customer value is, philosophically, about understanding human and business purposes and adoption and transaction processes. The core logic of customer value revolves around understanding and capturing customer expectations, creating and delivering desired customer experiences, and assessing and managing the customer evaluation. As illustrated in this study, these views are not mutually exclusive. Further studies should use fine-grained four dimensions (Table 3 ) to reach conceptual clarity. Traditional and emerging themes-customer value, as a perspective-dependent concept, accumulation across antecedents, dynamic activities, and focus on the economic potential of customer value-could serve as important catalysts for a more unified study of customer values. Taken together, customer value themes are evolving, primarily based on the notions of customer value as a widely studied concept, offering multi-perspective approaches for investigating customer value.

Studies in consumer research have been focused on explaining how consumers consider the value of a product (e.g. Kurt \& Inman, 2013) or how buyers estimate other buyers' purchase prices (Frederick, 2012). Conducting similar studies in the B2B context would improve our understanding to what extent we could generalize those results gained in consumer studies. In addition, experimental studies are rarely conducted in the B2B context which might also be worth of further research to experiment e.g. buyer's behaviour under business-to-business competition.

\section{Acknowledgements}

We wish to express our thanks to the people who helped us to improve the earlier versions of the paper that were presented in PICMET'12 and IAMOT'12 conferences. In addition we would like to thank the representatives of the case company.

\section{References}

ADNER, R.; KAPOOR, R. (2010). Value creation in innovation ecosystems: How the structure of technological interdependence affects firm performance in new technology generations. Strategic Management Journal, 31: 306-333. http://dx.doi.org/10.1002/smj.821

ANDERSON, J.C.; NARUS, J.A. (1999). Business Market Management: Understanding. Creating and Delivering Value (1st ed.). Upper Saddle River: Prentice-Hall.

ANDERSON, J.C.; NARUS, J.A.; VAN ROSSUM, W. (2006). Customer value propositions in business markets. Harvard Business Review, March: 91-99.

APPLEGATE, L. (2001). Emerging e-business models: lessons from the field. HBS, 9: 801-172. Boston: Harvard Business School. 
BAUMGARTNER, H.; PIETERS, R. (2008). Goal-directed consumer behavior in Consumer psychology (pp. 367-416-1273), C. Haugtvedt P., P. Herr M., \& F.R. Kardes (Eds.). New York: Taylor \& Francis Group.

BOLTON, R.N. (1998). A Dynamic Model of the Customer's Relationship With a Continuous Service Provider: The Role of Satisfaction. Marketing Science, 17(1): 45-65. http://dx.doi.org/10.1287/mksc.17.1.45

BOLTON, R.; LEMON, K.N.; VERHOEF, P.C. (2004). The Theoretical Underpinnings of Customer Asset Management: A Framework and Propositions for Future Research. Journal of the Academy of Marketing Science, 32(3):271-292. http://dx.doi.org/10.1177/0092070304263341

BOLTON, R.N.;DREW, J.H. (1991). A Multistage Model of Customers' Assessments of Service Quality and Value. Journal of Consumer Research, 17(March): 375-384. http://dx.doi.org/10.1086/208564

BUTZ, H.E.J.; GOOdSTEIN, L.D. (1996). Measuring Customer Value: Gaining the Strategic Advantage. Organisational Dynamics, 24(Winter): 63-77. http://dx.doi.org/10.1016/S00902616(96)90006-6

CAMERER, C.F.; FEHR, E. (2006). When does economic man dominate social behavior?. Science, 311: 47-52. http://dx.doi.org/10.1126/science.1110600

CHEN, Z.;DUBINSKY, A.J. (2003). A Conceptual Model of Perceived Customer Value in ECommerce: A preliminary Investigation. Psychology \& Marketing, 20(4): 323-347. http://dx.doi.org/10.1002/mar.10076

CHESBROUGH, H.; ROSENBLOOM, R.S. (2002). The role of the business model in capturing value from innovation: evidence from Xerox Corporation's technology spin-off companies. Industrial and Corporate Change, 11(3): 529-555. http://dx.doi.org/10.1093/icc/11.3.529

CHRISTOPHER, M. (1996). From brand values to customer value. Journal of Marketing Practice, 2(1): 55-66. http://dx.doi.org/10.1108/EUM0000000000007

COOPER, R.G. (2000). Doing it right. Winning with New Products. Ivey Business Journal, 64(6): 54-60.

DAVIS, F.D. (1989). Perceived Usefulness, Perceived Ease of Use, and User Acceptance of Information Technology. MIS Quarterly, 13(3): 319-340. http://dx.doi.org/10.1108/EUM0000000000007

EGGERT, A.; WOLFGANG, U. (2002). Customer perceived value: a substitute for satisfaction in business markets?. Journal of Business \& Industrial Marketing, 17(2/3): 107-118. http://dx.doi.org/10.1108/08858620210419754 
EGIDI, G.; NUSBAUM, H., C.; CACIOPPO, J., T. (2008). Neuroeconomics. Foundational Issues and Consumer Relevance in Consumer psychology (pp. 1177-1214-1273). C. Haugtvedt P., P. Herr M., \& F.R. Kardes (Eds.). New York: Taylor \& Francis Group.

FELLOWS, L.K. (2004). The Cognitive Neuroscience of Human Decision Making. Behavioural and Cognitive Neuroscience Reviews, 3: 159-172. http://dx.doi.org/10.1177/1534582304273251

FLINT, D. (2002). Compressing new product success-to-success cycle time. Deep customer value understanding and idea generation. Industrial Marketing Management, 31: 305-315. http://dx.doi.org/10.1016/S0019-8501(01)00165-1

FLINT, D.J.; WOODRUFF, R.B.; GARDIAL, S.F. (1997). Customer Value Change in Industrial Marketing Relationships. A Call for New Strategies and Research. Industrial Marketing Management. 26: 163-175. http://dx.doi.org/10.1016/S0019-8501(96)00112-5

FREDERICK, S. (2012). Overestimating Others' Willingness to Pay. Journal of Consumer Research, 39(June): 1-21. http://dx.doi.org/10.1086/662060

GALE, B.T. (1994). Managing Customer Value Creating quality and service that customers can see. New York: The Free Press.

GARRETT, J.;GOPALAKRISHNA, S. (2010). Customer value impact of sales contests. Academy of Marketing Science, 38: 775-786. http://dx.doi.org/10.1007/s11747-010-0187-4

GOODSTEIN, L.D.; BUTZ, H.E. (1998). Customer Value: The Linchpin of Organizational Change. Organizational Dynamics, 27(1): 21-34. http://dx.doi.org/10.1016/S0090-2616(98)900389

GORTH, J.C.; DYE, R.T. (1999). Service Quality: Perceived Value, Expectations, Shortfalls, and Bonuses. Managing Service Quality, 9(4): 174-285.

HAUGTVEDT, C.P.; HERR, P.M.; KARDES, F.R. (Eds.) (2008). Handbook of consumer psychology. New York: Taylor \& Francis Group.

HINES, P.; HOLWEG, M.; RICH, N. (2004). Learning to evolve. A review of contemporary lean thinking. International Journal of Operations \& Production Management, 24(10): 994-1011. http://dx.doi.org/10.1108/01443570410558049

HOLBROOK, M.B. (2005). Customer value and autoethnography: subjective personal introspection and the meanings of a photograph collection. Journal of Business Research, 25: 45-61. http://dx.doi.org/10.1016/S0148-2963(03)00079-1

HOOPER, M.J; , STEEPLE, D.; WINTERS, C.N. (2001). Costing customer value: an approach for the agile enterprise. International Journal of Operations \& Production Management, 21(5): 630-644. http://dx.doi.org/10.1108/01443570110390372 
HOWDEN, C.; PRESSEY, A.D. (2008). Customer value creation in professional service relationships: the case of credence goods. The Service Industries Journal, 28(6): 789-812. http://dx.doi.org/10.1080/02642060801990361

HSU, T.; LIN, L. (2006). QFD with Fuzzy and Entropy Weight for Evaluating Retail Customer Values. Total Quality Management, 17(7): 937-958.

HUBER, J.; LYNCH, J.; CORFMAN, K.; FELDMAN, J.; HOLBROOK, M.B.; LEHMANN, D. et al. (1997). Thinking About Values in Prospect and Retrospect: Maximising Experienced Utility. Marketing Letters, 8(3): 323-334. http://dx.doi.org/10.1023/A:1007964630841

JOHN, D.R. (1999). Consumer socialization of children: A retrospective look at twenty-five years of research. Journal of Consumer Research, 26: 183-213. http://dx.doi.org/10.1086/209559

KAHLE, L.R.; BEATTY, S. E.; HOMER, P. (1986). Alternative Measurement Approaches to Consumer Values: The list of Values (LOV) and Values and Life Style (VALS). Journal of Consumer Research, 13: 405-409. http://dx.doi.org/10.1086/209079

KAHLE, L.R.; XIE, G. (2008). Social values in consumer psychology in Consumer psychology (pp.575-585-1273). C. Haugtvedt P., P. Herr M. \& F.R. Kardes (Eds.). New York: Taylor \& Francis Group.

KEITH, R.J. (1960). The Marketing Revolution. Journal of Marketing, 24 (1): 25-38.

KURT, D.; INMAN, J.J. (2013). Mispredicting Others' Valuations: Self-Other Difference in the Context of Endowment. Journal of Consumer Research, 40(June): 78-89. http://dx.doi.org/10.1086/668888

LEBLANC, G.; NGUYEN, N. (1999). Listening to the Customers Voice: Examining Perceived Service Value Among Business College Students. The International Journal of Educational Management, 13(4): 187-198. http://dx.doi.org/10.1108/09513549910278106

LINDGREEN, A.; HINGLEY, M.K.; GRANT, D.B.; MORGAN, R.E. (2012). Value in business and industrial marketing: Past, present, and future. Industrial Marketing Management. 41(1): 207-214. http://dx.doi.org/10.1016/j.indmarman.2011.11.025

MONROE, K.B.; CHAPMAN, J.D. (1987). Framing effects on buyers' subjective product evaluations. Advances in Consumer Research, 14(1): 193-197.

MÄKINEN, S.J.; SEPPÄNEN, M. (2007). Assessing business model concepts with taxonomical research criteria: A preliminary study. Management Research News, 30(10): 735-748. http://dx.doi.org/10.1108/01409170710823458 
OLIVER, R.L. (1999a). Value as Excellence in the Consumption Experience in Consumer Value: A Framework for Analysis and Research (pp.43-62). M.B. Holbrook (Eds.). New York: Routledge.

OLIVER, R.L. (1999b). Whence Consumer Loyalty?. Journal of Marketing, 63(Special issue): 33-44. http://dx.doi.org/10.2307/1252099

OSTROM, A. IACOBUCCI, D. (1995). Consumer Trade-Offs and The Evaluation of Services. Journal of Marketing, 59(Jan.): 17-28. http://dx.doi.org/10.2307/1252011

PALMATIER, R.W. (2008). Inter-firm Relational Drivers of Customer Value. Journal of Marketing, 72(July): 76-89. http://dx.doi.org/10.1509/jmkg.72.4.76

PARASURAMAN, A. (1997). Reflections on Gaining Competitive Advantage Through Customer Value. Journal of the Academy of Marketing Science, 25(2): 154-161. http://dx.doi.org/10.1007/BF02894351

PARASURAMAN, A.; BERRY, L.L.; ZEITHAML, V.A. (1991). Refinement and Reassessment of the SERVQUAL Scale. Journal of Retailing, 67(4): 420-450.

PARASURAMAN, A.; ZEITHAML, V.A.; BERRY, L.L. (1988). SERVQUAL: A Multiple-Item Scale for Measuring Consumer Perceptions of Service Quality. Journal of Retailing, 64(1): 12-40.

PAYNE, A.; HOLT, S. (2001). Diagnosing Customer Value: Integrating the Value Process and Relationship Marketing. British Journal of Management, 12: 159-182. http://dx.doi.org/10.1111/1467-8551.00192

PEPPERS, D.; ROGERS, M. (2005). Return on customer (1st ed.). USA: Doubleday.

PORTER, M.E. (1991). Towards a Dynamic Theory of Strategy. Strategic Management Journal, 12(no. Special): 95-117.

PYNNÖNEN, M.; RITALA, P.; HALLIKAS, J. (2011). The new meaning of customer value: A systemic perspective. Journal of Business Strategy, 32(1): 51-57. http://dx.doi.org/10.1108/02756661111100328

RAVALD, A.; GRÖNROOS, C. (1996). The value concept and relationship marketing. European Journal of Marketing, 30(2): 19-30. http://dx.doi.org/10.1108/03090569610106626

ROGERS, E.M. (2003). Diffusion of Innovations (5th ed.). New York: The Free Press.

RUST, R.T.; OLIVER, R.L. (2000). Should We Delight the Customer?. Journal of the Academy of Marketing Science, 28(1): 86-94. http://dx.doi.org/10.1177/0092070300281008

SANCHEZ-FERNANDEZ, R.; INIESTA-BONILLO, M.A. (2007). The concept of perceived value: A systematic review of research. Marketing Theory, 7(4): 427-451. http://dx.doi.org/10.1177/1470593107083165 
SHETH, J.; MITTAL, B. (2004). Customer Behavior: A managerial Perspective (2nd ed.). USA: Thomson South-Western.

SHETH, J; NEWMAN, B.I.; GROSS, B.L. (1991). Consumption values and market choices. Theory and application. Cincinnati, Ohio, USA: South-Western Publishing Co.

SLATER, S.F.; NARVER, J.C. (1994). Market Orientation, Customer Value, and Superior Performance. Business Horizons, 37(March-April): 22-28. http://dx.doi.org/10.1016/00076813(94)90029-9

SLATER, S.F.; NARVER, J.C. (2000). Intelligence Generation and Superior Customer Value. Academy of Marketing Science, 1: 120-127. http://dx.doi.org/10.1177/0092070300281011

SPITERI, J.M.; DION, P.A. (2004). Customer value, overall satisfaction, end-user loyalty, and market performance in detail intensive industries. Industrial Marketing Management, 33: 675-687. http://dx.doi.org/10.1016/j.indmarman.2004.03.005

STAHL, H.K.; MATZLER, K.; HINTERHUBER, H.H. (2003). Linking customer lifetime value with shareholder value. Industrial Marketing Management, 32: 267-279. http://dx.doi.org/10.1016/S0019-8501(02)00188-8

TEECE, D.J. (2010). Business Models, Business Strategy and Innovation. Long range planning. http://dx.doi.org/10.1016/j.Irp.2009.07.003

TODD, D.J. (1979). Mixing Qualitative and Quantitative Methods: Triangulation in Action. Administrative Science Quarterly, 24(4): 602-611. http://dx.doi.org/10.2307/2392366

ULAGA, W.; CHACOUR, S. (2001). Measuring Customer-Perceived Value in Business Markets. A Prerequisite for Marketing Strategy Development and Implementation. Industrial Marketing Management, 30: 525-540. http://dx.doi.org/10.1016/S0019-8501(99)00122-4

ULWICK, A.W. (2005). What customers want Using outcome-driven innovation to create breakthrough products and services. New York: McGraw-Hill.

WOODALL, T. (2003). Conceptualising 'Value for the Customer': An Attributional, Structural and Dispositional Analysis. Academy of Marketing Science Review, 12: On-line version.

WOODRUFF, R.B.; GARDIAL, S.F. (1996). Know Your Customer. New Approaches to Understanding Customer Value and Satisfaction. Oxford, UK: Blackwell Publishing.

WOODRUFF, R.B. (1997). Customer Value. The Next Source for Competitive Advantage. Journal of Academy of Marketing Science, 25(2): 139-153. http://dx.doi.org/10.1007/BF02894350

ZEITHAML, V.A. (1988). Consumer perceptions of price, quality, and value: a means-end model and synthesis of evidence. Journal of Marketing, 52(July): 2-22. http://dx.doi.org/10.2307/1251446 
ZERBINI, F.; GOLFETTO, F.; GIBBERT, M. (2007). Marketing of competence: Exploring the resource-based content of value-for-customers through a case study analysis. Industrial Marketing Management, 36: 784-798. http://dx.doi.org/10.1016/j.indmarman.2006.06.005

ZOTT, C.; AMIT, R.; MASSA, L. (2011). The Business Model: Recent Developments and Future Research. Journal of Management, 1019-1042. http://dx.doi.org/10.1177/0149206311406265

ZUBAC, A.; HUBBARD, G.; JOHNSON, L., W. (2009). The RBV and value creation: a managerial perspective. European Business Review, 22(5): 515-538. http://dx.doi.org/10.1108/09555341011068921

Intangible Capital, 2013 (www.intangiblecapital.org)

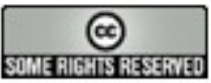

El artículo está con Reconocimiento-NoComercial 3.0 de Creative Commons. Puede copiarlo, distribuirlo y comunicarlo públicamente siempre que cite a su autor y a Intangible Capital. No lo utilice para fines comerciales. La licencia completa se puede consultar en http://creativecommons.org/licenses/by-nc/3.0/es/ 